\title{
The Effect of U.S. GAAP Compliance on Non-U.S. Firms' Cross-Listing Decisions and Listing Choices
}

\author{
Jing Lin \\ Haub School of Business, Saint Joseph's University \\ 5600 City Avenue, Philadelphia, PA 19131, U.S.A. \\ Tel: 1-610-660-3246Ｅ-mail: jlin@sju.edu
}

Received: July 26, 2011

Accepted: August 12, 2011

Published: November 1, 2011

doi:10.5539/ijef.v3n6p42

URL: http://dx.doi.org/10.5539/ ijef.v3n6p42

\begin{abstract}
This paper examines whether complying with U.S. financial reporting requirements impacts non-U.S. firms' cross-listing decisions and listing choices. Using two constructs (reconciliation and disclosure) established at the firm level to proxy for foreign firms' U.S. GAAP compliance costs, I find that compliance is a significant cost factor when non-U.S. firms consider whether they should issue or list their shares in the U.S. However, the importance of compliance costs diminishes when foreign firms decide whether they should cross-list on an organized U.S. stock exchange. The reduced significance of compliance costs is likely attributed to the various benefits associated with exchange-listing, which potentially outweigh the compliance costs. The study extends prior research by measuring a major cross-listing cost directly at the firm level. It offers a new perspective on the cost and benefits analyses and contributes to the understanding of the role accounting plays in foreign firms' cross-listing activities.
\end{abstract}

Keywords: Cross-listing, ADR, Accounting standards, U.S. GAAP, Compliance, Reconciliation, Disclosure

\section{Introduction}

This paper examines whether a non-U.S. firm's cost of complying with U.S. Generally Accepted Accounting Principles (GAAP) has an effect on its cross-listing decision and listing choices. For over a decade till the middle of 2000's, the U.S. market had seen a rapid growth of cross-border listing by foreign firms through the American Depository Receipts (ADRs) program. The number of cross-listed firms jumped from 158 in 1990 to more than 2,000 in 2006. Researchers across different disciplines have sought to understand the motives and impact of such a phenomenon and documented various benefits associated with U.S. listings, such as positive abnormal returns, reduced cost of capital, relax of capital constraint, lower private control benefits, improved firms' visibility, and higher firm values (see review papers by Karolyi 1998, 2006).

However, Leuz (2003) points out that the sources of cross-listing premium are not well understood and recommends introducing institutional variables and firm characteristics as explanatory variables to yield new insights. Despite the ADR surge, it is interesting to note that fewer than one in ten large public companies from outside the U.S. have chosen to cross-list in the U.S. (Doidge, Karolyi and Stulz 2004). Given all the benefits that cross-listing offers, one may wonder what inhibits more foreign companies from coming to the U.S. Since prior research has seldom looked at cross-listing activities directly from the cost side, such an investigation would help shed some lights on the issue. This study focuses on one major cross-listing cost: the cost of complying with U.S. GAAP.

U.S. GAAP is considered one of the highest quality sets of financial reporting standards in the world (Dye and Sunder 2001; Bradshaw, Bushee and Miller 2004). Many have suggested that the primary obstacle to a foreign company wishing to list securities in the U.S. is to meet the U.S. accounting and disclosure requirements (Rader 1994). Prior survey or case studies such as Mittoo (1992), Radebaugh, Gebhardt and Gray (1995), and Fanto and Karmel (1997) also provide anecdotal evidence to that effect. But there has been little archival research on the impact of U.S. GAAP compliance except early studies by Biddle and Saudagaran $(1989,1992)$ and a recent work by Hope, Kang and Zang (2007). While related to their study, this paper differs from Hope et al. (2007) in its focus on cost, a more comprehensive examination of U.S. GAAP compliance, and measuring key variables at the firm level.

Following Ashbaugh (2001), I disentangle the compliance costs into two components: reconciliation and disclosure. Data of these two constructs are taken from firms' accounting policies available on the Worldscope CDs. With the proxies, I attempt to address two questions. First, does meeting U.S. accounting and disclosure requirements impact foreign firms' decisions to cross-list in the U.S.? Second, for all the firms that have cross-listed, does complying 
with U.S. GAAP affect their listing choices? Foreign firms have four listing options: Rule 144a private placement, and Level I, II and III ADRs. Since Level II or III ADRs are exchange-listed, firms are required to conform to U.S. GAAP, whereas Rule 144a or Level I ADR firms are generally exempt from registration with the SEC. Despite their lower liquidity and visibility, Level I ADRs have experienced the largest growth (Frost and Lang 1996; Doidge et al. 2004). Thus whether U.S. GAAP compliance deters foreign firms from listing on a major U.S. exchange is an empirical question.

I find that complying with U.S. financial reporting requirements is a significant cost factor when non-U.S. firms decide whether they should issue or list their shares in the U.S. However, the significance of compliance costs diminishes when foreign firms determine whether or not they should cross-list on a stock exchange where U.S. GAAP compliance is required. It is possible that the benefits brought forth through exchange-listing outweigh the compliance costs. Recently the SEC removes the reconciliation requirement for foreign registrants which prepare their financial statements using International Financial Reporting Standards (IFRS) as issued by the International Accounting Standards Board (IASB). Though this decision by the SEC is primarily geared toward supporting IASB's goal of providing a common language of financial reporting around the world, its decision offers indirect support to my finding concerning the role reconciliation cost plays in foreign firms' cross-listing activities.

To my knowledge, no prior studies have empirically examined the effect of reconciliation on foreign firms' cross-listing decisions and listing choices. In terms of disclosure, different from prior studies that use disclosure index constructed at the country-level such as CIFAR, current study builds the disclosure index at the firm-level. Since a firm's decision of coming to the U.S. depends mainly on company-specific factors, this firm-level design can better capture the effect of disclosure variation on cross-listing decisions. As Hope (2003) notes, a limitation of using country-level disclosure scores is that the within-country variation in firm disclosures can be as great as between-country variation. In addition, since this disclosure index includes more items on accounting method choices than CIFAR covers, it should result in a more accurate measurement of disclosure cost. Today the international integration of capital markets has led to unprecedented levels of competition among stock exchanges. Exchanges around the globe are trying to attract more foreign listings (Pagano, Roell and Zechner 2002). As such, U.S. regulators, accounting standard-setters, exchange officials, corporate managers, and investors should find the results interesting.

The paper is structured as follows. Section 2 discusses ADR background and cross-listing theories. Section 3 develops the research design and hypotheses. Section 4 presents variables and empirical models. Section 5 outlines data sources and sample selection procedures. Section 6 documents findings. Section 7 reports sensitivity analyses. Section 8 concludes with limitations and potential future research direction.

\section{Background and Theories}

Over the years, ADR has become a popular vehicle for foreign firms to enter the U.S. capital markets. Four types of ADR instruments are available: private offerings made under Rule 144a of the Securities Act of 1933 and three types of public placement (Level I, II, and III). Private placement and Level I ADRs are exempt from conforming to the SEC's accounting and disclosure requirements. Foreign firms listed via Level II or III ADRs must register with the SEC and can trade their ADRs on one of the major U.S. exchanges (NYSE, AMEX, or NASDAQ). Besides listing existing stocks, Level III ADRs can also raise capital through issuing new shares.

Registration with the SEC obligates Level II and III ADR firms to provide financial information under U.S. GAAP annually in Form 20-F and periodically in Form 6-K. These firms can prepare their financial statements using U.S. GAAP, or IAS/IFRS or their home-country standards with a reconciliation of net income and stockholders' equity figures equivalent to that under U.S. GAAP. Though reconciliation requirement is recently removed for firms following IFRS reporting, foreign registrants still need to comply with disclosure rules through Form 20-F filings such as Item 17 and Item 18. Item 18 is required for securities offerings and typically calls for vastly expanded footnote disclosure, including virtually all required U.S. disclosure.

Prior studies have proposed different theories to identify potential factors in driving firms' cross-listing decisions. The market segmentation hypothesis emphasizes that the world markets are segmented by different kinds of barriers to capital flows, causing additional risks to be borne by stocks in a country segmented from foreign investors (Errunza and Losq 1985). To reduce the investment barriers, foreign firms have incentives to list their shares in the U.S. As predicted, Foerster and Karolyi (1999), and Miller (1999) document a small positive reaction to the listing or the announcement of listing, and Errunza and Miller (2000) find a decline in the cost of capital after ADR listing.

Merton's (1987) investor recognition hypothesis states that investors consider only securities that they know. Firms with a relatively small shareholder base have incentives to incorporate policies that actively expand the investor base 
of the firm's shares, including listing shares on foreign exchanges. Baker, Nofsinger and Weaver (2002) show that firms with increased investment base have lower cost of capital and higher market value of shares.

The liquidity hypothesis says that since the U.S. capital markets are deep and liquid, firms with ADR listings can raise funds at a lower cost than at home, especially companies from emerging markets (Lins, Strickland and Zenner 2005). Focusing on Mexican firms, Davis-Friday, Frecka and Rivera (2005) show that Mexican ADR firms issue equity on U.S. exchanges to relax capital constraints which became very severe after the 1995 peso devaluation.

Built upon the seminal work of La Porta, Lopez-de-Silanes, Shleifer and Vishny (1998) that countries differ in their protections of minority shareholders and enforcement strength, the bonding hypothesis argues that a company from countries with low investor protections can "bond" itself with the U.S. where investor protections are high (Coffee 1999; Stulz 1999). U.S. disclosure requirement and litigation threat would force foreign firms to respect minority shareholder rights and increase the amount of disclosed information. This in turn will lower their cost of capital. Papers such as Reese and Weisbach (2002) and Doidge et al. (2004) find support to the bonding argument.

Finally, the signaling hypothesis states that information considerations are a key factor in cross-listing decisions. Analytical models by Cantale (1996), Fuerst (1998) and Moel (1999) suggest that firms have incentive to list in the U.S. as an attempt to signal their private information on unobservable good qualities to outside investors. This incentive is particularly appealing for firms domiciled in low disclosure quality and low information trading environments. In sum, the overall evidence points to the fact that listing in the U.S. is associated with many benefits.

\section{Research Design and Hypotheses Development}

Prior literature has identified complying with U.S. GAAP as one of the most significant listing costs. Saudagaran and Biddle (1992) claims that the stringent U.S. disclosure requirement deters foreign companies from listing shares in the U.S. Mittoo (1992) surveys the managers of Canadian companies that are cross-listed in the U.S. and the U.K. and finds that managers view meeting the SEC reporting requirements as their No. 1 cost. In a case study which examines Daimler-Benz's decision to list its existing shares on the NYSE in 1993, Radebaugh et al. (1995) state that the significant difference between German and U.S. GAAP is the main reason that relatively few German firms are listed in the U.S. In a survey by Fanto and Karmel (1997) on the attitudes of foreign companies regarding U.S. listing, more than half of the respondents consider accounting reconciliation time-consuming and expensive. Foreign managers also complained about the extensiveness of U.S. disclosure requirements.

Though much of the existing evidence is drawn from surveys or case studies, a consistent theme emerges that the cost of meeting U.S. financial reporting requirements is a primary consideration as foreign firms contemplate U.S. listing. Therefore, my general hypothesis is that the cost of complying with U.S. GAAP negatively affects non-U.S. firms' cross-listing attempts.

Ashbaugh (2001) suggests that each set of accounting standards is a unique combination of accounting measurement policies and disclosure. Firms incur differential costs to disclose IAS/U.S. financial information since not all firms report such information in their annual reports. Explicit costs are due to the information collection and processing costs incurred by converting a domestic GAAP accounting system into a system in conformity with IAS or U.S. GAAP. As for disclosure, the required disclosures can impose out-of-pocket costs on firms if data are not already produced for internal reporting purposes. The additional disclosures may also impose implicit costs on a firm if such disclosures place a firm at a competitive disadvantage when competitors do not publish similar information.

Accordingly, I separate U.S. GAAP compliance into two components: reconciliation and disclosure, and predict that each cost will negatively affect the firm's decision to cross-list in the U.S.

\section{H1: Non-U.S. firms with higher reconciliation costs and/or higher disclosure costs will be less likely to cross-list in the U.S., ceteris paribus.}

Since only exchange-listed firms (Level II and III ADRs) are required to follow the accounting rules and regulations in the U.S., I predict that an ADR firm's reconciliation costs and disclosure costs will each negatively affect its decision to list on a major U.S. exchange.

\section{H2: Cross-listed firms with higher reconciliation costs and/or disclosure costs will be less likely to list on an organized exchange, ceteris paribus.}

\section{Variables and Empirical Models}

To operationalize the reconciliation construct, I adopt a metric of 13 accounting policies developed by Bradshaw, Bushee and Miller (2004) (see Appendix A). By comparing a firm's individual accounting policies to the respective U.S. standard, I obtain a score describing the distance of a firm's accounting choices from the U.S. benchmarks. The more items that are different, the higher the reconciliation costs, as more effort and time are 
needed to convert accounting information suiting a home standard to the U.S. standard. Disclosure is measured based on whether a firm provides information on 29 accounting method choices and on auditor and auditor's opinion (see Appendix B). This metric is constructed at the firm level.

\subsection{Cross-Listing Decisions}

I test non-U.S. firms' cross-listing decisions (H1) by estimating the following logit model:

$$
\begin{gathered}
C L=\alpha_{0}+\alpha_{1} \text { Reconcile }+\alpha_{2} \text { Disclosure }+\alpha_{3} \text { CIFAR }+\alpha_{4} \text { InvestProtec }+\alpha_{5} \text { EmergM }+\alpha_{6} \text { Liquidity }+\alpha_{7} \text { LogGNP }+ \\
\alpha_{8} \text { Size }+\alpha_{9} \text { Growth }+\alpha_{10} \text { Leverage }+\alpha_{11} \text { Industry }+\varepsilon
\end{gathered}
$$

The dependent variable $C L$ is an indicator variable that takes the value of one if a firm cross-lists in the U.S. and zero otherwise. Reconcile represents the reconciliation costs incurred by a firm to bring its accounting numbers in line with U.S. GAAP. Of the 13 accounting policies, if a firm's accounting choice is different from that of the U.S., I assign one point to that item, indicating that it is more costly for the firm to comply with U.S. GAAP in that area. After adding up these one points, i.e., total number of noncompliant items, I divide the sum by 13 to get the value of Reconcile which ranges from 0 ( $100 \%$ compliant) to 1 (100\% noncompliant).

Disclosure is a proxy for firms' potential cost of following U.S. reporting rules to make information available to users of financial statements. Out of the 31 items as listed on Appendix B, if a foreign firm does not disclose one policy, I assign one point to that item. After adding up these one points, i.e., total number of non-disclosed items, I divide the sum by 31 to get the value of Disclosure which ranges from 0 (100\% disclosed) to 1 (100\% non-disclosed). According to H1, a negative sign is predicted for these two test variables.

In addition, I include several country-level and firm-level variables to control for factors expected to influence a firm's cross-listing decision. CIFAR is added to reflect home-country disclosure environment. InvestProtec is a proxy for shareholder protection in the home country. I adopt three separate measures from La Porta et al. (1998): (1) legal tradition of the home country (French, German, Scandinavian Civil Law, or English Common Law); (2) an index of anti-director rights, which aggregates six important shareholder rights within a country; (3) an index of judicial efficiency. Since firms from emerging markets face more capital constraints than those from developed markets, I include a dummy variable Emerg $M$ which equals one if a firm's home market is classified as emerging by the International Finance Corporation, and zero otherwise. Liquidity, a ratio of the dollar value of shares traded by the average market capitalization in 1997, is used to control for the liquidity of the home capital market. Log of GNP controls for the size of the home market since firms from smaller markets have greater incentives to access the larger U.S. investor base.

At the firm-level, Size equals the log of total assets in millions of U.S. dollars. Since valuable growth opportunities motivate firms to engage in cross-listing activities, Growth is included which equals the percentage of a firm's net sales growth. Leverage reflects a firm's demand for external capital and equals the percentage of long-term debt over common equity. Finally, Industry is a firm's industry membership classified according to 1-digit SIC code.

\subsection{Cross-Listing Choices}

Similar to estimating equation (1), I use a logit model to test cross-listed firms' listing choices (H2):

$$
\begin{array}{r}
E X_{-} C L=\alpha_{0}+\alpha_{1} \text { Reconcile }+\alpha_{2} \text { Disclosure }+\alpha_{3} \text { CIFAR }+\alpha_{4} \text { InvestProtec }+\alpha_{5} \text { EmergM }+\alpha_{6} \text { Liquidity }+\alpha_{7} \text { LogGNP } \\
+\alpha_{8} \text { Size }+\alpha_{9} \text { Growth }+\alpha_{10} \text { Leverage }+\alpha_{11} \text { Industry }+\varepsilon
\end{array}
$$

The dependent variable, $E X_{-} C L$, takes the value of one if a firm cross-lists on a major U.S. exchange, and zero if a firm cross-lists under Rule $144 \mathrm{a}$ or as Level I ADR. As H2 predicts, Reconcile and Disclosure are expected to have negative signs. According to Hope et al. (2007), CIFAR should have a positive sign as managers of firms domiciled in a better disclosure environment are less concerned about their loss of private control benefits resulting from complying with U.S. financial reporting requirements. The sign predictions for the rest of the variables are the same as those under equation (1).

\section{Sample and Data Sources}

I obtain samples from the Worldscope Global Compact D. Besides financial data, Worldscope collects information from a firm's annual reports the 31 accounting policies adopted. However, after August 2001 Worldscope decided to collect only three items of these policies. I chose 1999 as the sample cutoff year because it gives me the largest number of firms that have the accounting policy data available. An initial sample of 14,376 firms is taken from the June 2000 and June 2001 CDs. I exclude 947 firms for lack of country-level variables such as CIFAR or investor protection. I delete another 5,025 firms that had total assets less than US \$100 million, the same size cutoff point adopted by Doidge et al. (2004) and Hope et al. (2007). I also lose 865 firms that did not have accounting policy 
data and 813 firms that have missing information on firm-level variables such as total assets. Finally, 72 non-U.S. firms indicated that they followed U.S. GAAP, the exclusion of which gives me a final sample of 6,654 firms.

I obtain the list of cross-listed firms from the websites of the Bank of New York (www.adrbny.com) and JP Morgan's "ADR Universe" (www.adr.com). I check each sample firm against this list to determine its cross-listing status as of December 31, 1999. A total of 533 cross-listed firms are identified. Among them, 111 firms were traded under Rule 144a, 289 firms were Level I ADRs, 74 were Level II ADRs, and 59 were Level III ADRs. The remaining 6,121 firms were not cross-listed in the U.S. as of December 31, 1999. The sample represents firms from 35 countries. Table 1 gives the distribution of firms by countries and listing modes.

\section{Results}

\subsection{Univariate Analyses}

The descriptive statistics in Table 2 show that ADR firms account for $8 \%$ of the sample, consistent with the statement that less than $10 \%$ of publicly-held companies from foreign countries are cross-listed in the U.S. (Doidge et al. 2004). Two percent of the firms were exchange-listed. On average, firms were about $23 \%$ noncompliant with U.S. GAAP on the 13 accounting policies (Reconcile) and did not disclose about $36 \%$ of their accounting choices on the 31 items identified in the paper (Disclosure).

Table 3 reports the comparison of means and medians of variables for cross-listed and non cross-listed firms. Values of Reconcile and Disclosure are both higher for non cross-listed firms than that of cross-listed firms, suggesting that cross-listed firms incurred lower Reconcile and Disclosure costs. Consistent with bonding hypothesis, judicial efficiency of cross-listed firms is statistically significantly lower than that of non cross-listed firms. About $37 \%$ of cross-listed firms are from an emerging market economy, while $18 \%$ of non cross-listed firms domicile in an emerging market, lending support to liquidity hypothesis. Cross-listed firms tend to domicile in a smaller market, which is in line with the investor recognition hypothesis. At the firm level, cross-listed firms are larger, have higher growth rate and are also more profitable than non cross-listed firms.

Table 4 presents the comparison of means and medians of exchange-listed and other cross-listed firms that are not exchange-listed. The mean of Reconcile for exchange-listed firms is lower than that of non exchange-listed firms, though the difference is not statistically significant. Similarly, exchange-listed firms tend to have lower Disclosure value and the differences in means and medians are statistically significant, suggesting that firms disclosing more information under their home country GAAPs are more likely to list on a U.S. exchange.

Consistent with Hope et al. (2007), exchange-listed firms have higher CIFAR score than non exchange-listed firms, indicating that firms from a lower disclosure regime are less likely to list on an organized exchange where U.S. GAAP compliance is required. Exchange-listed firms tend to come from a home capital market that has lower liquidity. At the firm level, exchange-listed firms are larger and more profitable, but not necessarily the high growth or more leveraged firms. Overall, the univariate analyses provide support for $\mathrm{H} 1$ and the disclosure aspect of $\mathrm{H} 2$.

\subsection{Multivariate Analyses}

Before conducting the multivariate analyses, I check the correlation of regression variables (results not tabulated here). Two test variables Reconcile and Disclosure are positively correlated but the correlation is not strong ( $\rho=$ 0.21 ). They are not highly correlated with other control variables. CIFAR is positively correlated with anti-director rights and judicial efficiency and negatively correlated with Liquidity. Emerging market variable is negatively correlated with judicial efficiency and the size of the home market $(\log G N P)$, and the last two variables are also positively correlated with each other. I calculate the variance inflation factors (VIFs). The VIF scores are not high, suggesting that there is no strong multicollinearity problem.

\subsubsection{Cross-Listing Decisions}

Table 5 reports the results from estimating equation (1) where I specify three models. As more control variables are added to the model, the explanatory power (pseudo $\mathrm{R}^{2}$ ) of the models increases from $8.3 \%$ to $23.6 \%$. Consistent with H1, the coefficients on the two test variables Reconcile and Disclosure are both negative and significant across all three models, indicating that firms incurring higher U.S. GAAP compliance costs are less likely to cross-list.

To better explain the impact of Reconcile and Disclosure on cross-listing decisions, I conduct the marginal effect analysis (dy/dx) to show the impact of one unit change in the independent variable (from 0 to 1 ) on one unit change of the dependent variable (from 0 to 1 ), which is the change in cross-listing probability from non cross-listing to cross-listing. Table 5 lists the marginal effect coefficients. In Model 3, the coefficient on Reconcile is -0.024 , suggesting that if a non-U.S. firm changes its 13 accounting policies from being fully non-compliant to being fully compliant (i.e., Reconcile changes from 1 to 0 ), the predicted probability of cross-listing would increase by 2.4 
percentage points, or $30 \%(2.4 / 8)$, since the average probability of cross-listing is $8 \%$ (the mean of $C L$ ). In other words, each change in accounting method to be compliant with U.S. practices (1/13 increase) would increase the predicted probability of cross-listing by 0.185 percentage points $(0.024 \times 1 / 13)$, equivalent to a $2.3 \%(0.185 / 8)$ increase in cross-listing probability.

Likewise, the coefficient on Disclosure is -0.043 , suggesting that a change by a foreign firm from the state of full non-disclosure on the 31 accounting policies to full disclosure (i.e., Disclosure changes from 1 to 0 ) would increase its cross-listing probability by 4.3 percentage points, or $54 \%$ (4.3/8). In other words, increased disclosure on each accounting policy $(1 / 31$ increase) would increase the predicted cross-listing probability by 0.139 percentage points $(0.043 \times 1 / 31)$, or $1.74 \%(0.139 / 8)$.

Table 5 further shows that the coefficient on CIFAR stays negative and significant, indicating that firms originating from a lower disclosure regime are more likely to cross-list. The coefficient of the anti-director rights is positively significant, suggesting that firms domiciled in a country with stronger investor protection have higher probability of cross-listing in the U.S. The coefficients of the three variables of code law tradition are all negative, suggesting that foreign firms from a common law origin are more likely to cross-list. At the firm level, larger firms are more likely to cross-list, consistent with the notion that larger companies can bear the compliance costs better than smaller ones. Leverage has a negative coefficient, suggesting that the more leveraged firms are less likely to cross-list.

\subsubsection{Cross-Listing Choices}

Table 6 shows the results from estimating equation (2), which assesses the probability of cross-listing on a major U.S. stock exchange by cross-listed firms. Three models are specified using 533 cross-listed firms with the explanatory power (pseudo $\mathrm{R}^{2}$ ) ranging from $17.7 \%$ to $28.4 \%$. The coefficient of Reconcile is negative but not significant, suggesting that reconciliation is not necessarily a relevant factor when non-U.S. firms determine whether to list on a stock exchange or not. In other words, high reconciliation costs do not appear to hinder firms from listing on an exchange. Disclosure has the predicted negative sign but is significant only for the first two models. When additional control variables are introduced into model 3, Disclosure loses its significance. The results suggest that disclosure costs have limited influence. When all benefits and costs are considered, firms bearing higher disclosure costs are as likely to exchange-list as firms incurring lower disclosure costs.

The impact of home country disclosure environment (CIFAR) stays strong, consistent with the main finding of Hope et al. (2007) that firms originating from a higher disclosure regime are more likely to exchange-list. The emerging market economy continues to be an important factor in listing choices. At the firm level, bigger firms tend to exchange-list more probably because they can bear the high compliance costs better than smaller firms.

In sum, the multivariate analyses from the above two sections find support for $\mathrm{H} 1$ but only marginally for $\mathrm{H} 2$. Thus, complying with U.S. GAAP appears to be a cost hurdle for non-U.S. firms when considering whether they should come to the U.S. market, but the importance of compliance costs diminishes when firms determine where to list their stocks. It appears that factors other than compliance costs are more important in choosing where to list shares. One possible explanation is that the benefits of exchange-listing, such as decrease in the cost of capital, relaxation of capital constraints, improvement in visibility, and higher firm values, outweigh the compliance costs.

\section{Sensitivity Analyses}

\subsection{The Endogeneity of Compliance Costs}

As $\mathrm{H} 1$ predicts, non-U.S. firms incurring lower compliance costs are more likely to engage in cross-listing activities. However, it is also likely that a firm, in anticipation of future ADR listing, will move its accounting practices closer to U.S. GAAP and/or increase its disclosure gradually. Lang et al. (2003) suggest that firms appear to change local accounting choices in preparation for cross-listing. To mitigate the potential endogeneity concerns, I identify sample firms that disclose accounting practices both in the cross-listing years and three years prior to their cross-listings and compare their compliance costs for the two periods.

Among the 533 cross-listed firms, 208 have accounting and disclosure data for the two years. I group them by their respective cross-listing years and compute the means of Reconcile and Disclosure for the two years in comparison. Table 7 shows their distributions in seven sub-groups by their respective cross-listing years. It appears that, on average, firms incurred lower compliance costs in the cross-listing year than in earlier years. But except for a group of firms cross-listed in 1994 that has significantly lower reconciliation costs in 1994 than in 1991, the majority of the mean differences are not statistically significant. The comparison indicates that these sample firms' local accounting practices remain fairly stable between the two periods, which reduces the endogeneity concerns. 


\subsection{Analysis Using Country-Fixed Effect}

For the basic findings of $\mathrm{H} 1$ and $\mathrm{H} 2$, some unobservable country-level variables may drive the results. To capture the effect of potentially important country variables, I estimate equation (1) and (2) by introducing country dummy variables in the logit regression and excluding all other country-level variables. Table 8 presents the logit regression results of country-fixed effect. For cross-listing, the coefficients of Reconcile and Disclosure are negative and significant, supporting the baseline results of $\mathrm{H} 1$. For exchange-listing, the coefficient of Reconcile is not significant, but Disclosure has a negative and significant coefficient, supporting H2's idea that firms incurring more disclosure costs are less likely to list on a stock exchange. This outcome indicates that disclosure matters.

\subsection{Logit Regressions Using Alternative Variable Definitions}

One limitation of current study is measuring compliance costs by using a simple count of accounting method choices, which essentially assigns equal weight to every item. In reality, different accounting choices should have different implications to companies and some should be weighed more heavily than others. To mitigate this issue, I categorize reconcile and disclosure each into three levels: high, medium and low, based on their respective sample distributions. Using the medium group as the base, I include the high and low groups in the regression. This treatment recognizes that firms in the high group should have compliance costs that are quite different from those in the low group, which allows better comprehension of the role of compliance costs in firms' cross-listing and exchange-listing decisions. Table 9 presents the logit regression results using the following alternative test variables: $L_{-} R e c, H_{-} R e c, L_{-} D i s$, and $H_{-}$Dis. The baseline findings of $\mathrm{H} 1$ are confirmed that foreign firms bearing lower compliance costs are more likely to cross-list while firms having higher compliance costs are less likely to cross-list.

\section{Conclusions, Limitations and Future Research}

This paper studies whether complying with U.S. GAAP impacts non-U.S. firms' cross-listing decisions and listing choices. This investigation is important, given the rapid growth of cross-listing in the U.S. and the increasing capital market integration around the globe. By directly examining a major cross-listing cost at the firm level, this study provides a new perspective on foreign firms' cost and benefit analysis.

Consistent with earlier survey and case studies, I find that complying with U.S. financial reporting requirements is a significant cost factor when non-U.S. firms consider whether they should issue or list their shares in the U.S. However, the importance of compliance costs diminishes when foreign firms contemplate whether they should list on an organized stock exchange where U.S. GAAP compliance is required. This finding is likely attributable to the fact that an exchange-listing gives foreign firms various benefits which potentially outweigh the compliance costs.

Current study contributes to the understanding of the role accounting plays in non-U.S firms' decision-making processes. From the standpoint of the U.S. accounting regulator (the SEC) and standard-setters, the evidence presented in this paper indicates that U.S. accounting and disclosure requirements do hinder potential non-U.S. firms from listing or issuing shares in the U.S. markets. As stock exchanges around the world are trying to attract more foreign listings, the findings provide support to the SEC's recent removal of reconciliation requirement for those firms which prepare financial statements using IFRS.

The study is subject to some limitations. First, the models may omit some potential relevant variables. For example, theory has proposed that when private control benefits are high, controlling shareholders are less likely to choose to list their shares in the U.S. With no access to firms' ownership data, I am unable to control for the influence of controlling shareholders on cross-listing decisions. However, by including investor protection variables, I mitigate the problem to some extent. Second, the examination of 13 accounting choices may not necessarily capture the full reconciliation cost, and the self-constructed disclosure index does not cover the complete list of disclosure items.

Future research can study the impact of Sarbanes-Oxley Act (SOX) on foreign firms' cross-listing activities. It is possible that more firms will prefer to list as 144a or Level I ADRs, to avoid the large SOX compliance cost. It will be interesting to examine the accounting and disclosure practices of these non exchange-listed firms. The evidence produced will be relevant for assessing information that companies disclose in the absence of reporting requirements under the Exchange Act (Frost and Lang 1996). Future research can also identify firm and country characteristics associated with delisting due to the SOX compliance requirements imposed on foreign registrants.

\section{References}

Ashbaugh, H. (2001). Non-US Firms' Accounting Standard Choices. Journal of Accounting and Public Policy 20: 129-153. http://dx.doi.org/10.1016/S0278-4254(01)00025-4

Baker, H. K., J. R. Nofsinger, and D. G. Weaver. (2002). International Cross-Listing and Visibility. Journal of Financial and Quantitative Analysis 37: 495-521. http://dx.doi.org/10.2307/3594990 
Biddle, G. and S. Saudagaran. (1989). Financial Disclosure Levels and Foreign Stock Exchange Listing Decisions. Journal of International Financial Management and Accounting 4: 06-148.

Bradshaw, M.T., B. J. Bushee, and G.S. Miller. (2004). Accounting choice, home bias, and U.S. investment in Non-U.S. firms. Journal of Accounting Research 42 (5): 795-841. http://dx.doi.org/10.1111/j.1475-679X.2004.00157.x

Cantale, S. (1996). The choice of a foreign market as a signal. INSEAD working paper.

Coffee, J. (1999). The Future as History: The Prospects for Global Convergence in Corporate Governance and its Implications. Northwestern University Law Review 93: 641-708.

Davis-Friday, P., T.J. Frecka, and J.M. Riviera. (2005). The financial performance, capital constraints and financial reporting environment of cross listed firms: Evidence from Mexico. The International Journal of Accounting 40: 1-30. http://dx.doi.org/10.1016/j.intacc.2005.01.001

Doidge, C., G. A. Karolyi, and R. Stulz. (2004). Why are Foreign Firms that are Listed in the U.S. Worth More? Journal of Financial Economics 71: 205-238. http://dx.doi.org/10.1016/S0304-405X(03)00183-1

Dye, R. and S. Sunder. (2001). Why not allow the FASB and the IASB Standards to Compete in the U.S.? Accounting Horizons 15(3): 257-271. http://dx.doi.org/10.2308/acch.2001.15.3.257

Errunza, V. and E. Losq. (1985). International asset pricing under mild segmentation: Theory and test. The Journal of Finance 40: 105-124. http://dx.doi.org/10.2307/2328050

Errunza, V. R. and D. P. Miller. (2000). Market Segmentation and the Cost of Capital in International Equity Markets. Journal of Financial and Quantitative Analysis 35: 577-600. http://dx.doi.org/10.2307/2676256

Fanto, J.A. and R.S. Karmel. (1997). A report on the attitudes of foreign companies regarding a US Listing. Stanford Journal of Law, Business \& Finance 3: 51-83.

Foerster, S. R. and G. A. Karolyi. (1999). The Effects of Market Segmentation and Investor Recognition on Asset Prices: Evidence from Foreign Stocks Listing in the United States. Journal of Finance 54: 981-1013. http://dx.doi.org/10.1111/0022-1082.00134

Frost, C. A. and M. H. Lang. (1996). Foreign Companies and U.S. Securities Markets: Financial Reporting Policy Issues and Suggestions for Research. Accounting Horizons 10: 95-109.

Fuerst, O. (1998). A Theoretical Analysis of the Investor Protection Regulations Argument for Global Listing of Stocks. Working paper, Yale University.

Hope, O-K. (2003). Disclosure practices, enforcement of accounting standards and analysts' forecast accuracy: An international study. Journal of Accounting Research 41 (2): 235-271. http://dx.doi.org/10.1111/1475-679X.00102

Hope, O-K, T. Kang, and Y. Zang. (2007). Bonding to the Improved Disclosure Environment in the United States: Firms' Listing Choices and their Capital Market Consequences. Journal of Contemporary Accounting and Economics, 3(1), 1-33. http://dx.doi.org/10.1016/S1815-5669(10)70011-4

Karolyi, G. A. (1998). Why do Companies List Shares Abroad? A Survey of the Evidence and its Managerial Implications. Financial Markets, Institutions and Instruments 7:1-60. http://dx.doi.org/10.1111/1468-0416.00018

Karolyi, A. G. (2006). The World of Cross-Listings and Cross-Listings of the World: Challenging Conventional Wisdom. Review of Finance, 10(1), 99-152. http://dx.doi.org/10.1007/s10679-006-6980-8

La Porta, R., F. Lopez-de-Silanes, A. Shleifer, and R. W. Vishny. (1998). Law and Finance. Journal of Political Economy 106: 1113-1155. http://dx.doi.org/10.1086/250042

Lang, M., J. S. Raedy, and M. Yetman. (2003). How Representative are Cross-Listed Firms? An Analysis of Firm Performance and Accounting Quality. Journal of Accounting Research 41(2): 363-396. http://dx.doi.org/10.1111/1475-679X.00108

Leuz, C. (2003). Discussion of ADRs, analysts, and accuracy: Does cross-listing in the United States improve a firm's information environment and increase market value? Journal of Accounting Research 41 (2): 347-362. http://dx.doi.org/10.1111/1475-679X.00107

Lins, K., D. Strickland, and M. Zenner. (2005). Do Non-U.S. Firms Issue Equity on U.S. Exchanges to Relax Capital Constraints? Journal of Financial and Quantitative Analysis 40(1): 109-133. http://dx.doi.org/10.1017/S0022109000001769 
Merton, R. C. (1987). Presidential Address: A Simple Model of Capital Market Equilibrium with Incomplete Information. Journal of Finance 42: 483-510. http://dx.doi.org/10.2307/2328367

Miller, D. P. (1999). The Market Reaction to International Cross-Listing: Evidence from Depositary Receipts. Journal of Financial Economics 51: 103-123. http://dx.doi.org/10.1016/S0304-405X(98)00045-2

Mittoo, U. (1992). Managerial Perceptions of the Net Benefits of Foreign Listing; Canadian Evidence. Journal of International Financial Management and Accounting 40 http://dx.doi.org/10.1111/j.1467-646X.1992.tb00021.x

Moel, A. (1999). The Role of Information Disclosure on Stock Market Listing Decisions: the Case of Foreign Firms Listing in the U.S. Working paper, Harvard Business School.

Pagano, M., A. Roell, and J. Zechner. (2002). The Geography of Equity Listing: Why Do Companies List Abroad? The Journal of Finance 57(6): 2651-2694. http://dx.doi.org/10.1111/1540-6261.00509

Radebaugh, L.H., G. Gebhardt, and S. J. Gray. (1995). Foreign Stock Exchange Listings: A Case Study of Daimler-Benz. Journal of International Financial Management and Accounting 6: 158-192. http://dx.doi.org/10.1111/j.1467-646X.1995.tb00055.x

Rader, E. (1994). Accounting Issues in Cross-Border Securities Offerings. Fordham International Law Journal 17 (1994): S129-S139.

Reese, W. A. J. and M. S. Weisbach. (2002). Protection Of Minority Shareholder Interests, Cross-Listings in the United States, and Subsequent Equity Offerings. Journal of Financial Economics 66: 65-104. http://dx.doi.org/10.1016/S0304-405X(02)00151-4

Saudagaran, S. and G. Biddle. (1992). Financial disclosure levels and foreign stock exchange listing decisions. Journal of International Financial Management and Accounting 4: 106-148. http://dx.doi.org/10.1111/j.1467-646X.1992.tb00025.x

Stulz, R. M. (1999). Globalization, Corporate Finance, and the Cost of Capital. Journal of Applied Corporate Finance 12: 8-25. http://dx.doi.org/10.1111/j.1745-6622.1999.tb00027.x 
Table 1. Distributions by Country and Listing Types

\begin{tabular}{|c|c|c|c|c|c|c|c|}
\hline Country & Total & NCL Firms & CL Firms & Rule 144a & Level I & Level II & Level III \\
\hline Argentina & 36 & 25 & 11 & 4 & 0 & 3 & 4 \\
\hline Australia & 201 & 179 & 22 & 3 & 12 & 5 & 2 \\
\hline Austria & 56 & 48 & 8 & 0 & 8 & 0 & 0 \\
\hline Belgium & 72 & 70 & 2 & 0 & 2 & 0 & 0 \\
\hline Brazil & 87 & 75 & 12 & 1 & 5 & 5 & 1 \\
\hline Chile & 66 & 58 & 8 & 0 & 0 & 0 & 8 \\
\hline Denmark & 105 & 102 & 3 & 0 & 2 & 0 & 1 \\
\hline Finland & 62 & 57 & 5 & 1 & 1 & 2 & 1 \\
\hline France & 312 & 294 & 18 & 1 & 9 & 2 & 6 \\
\hline Germany & 318 & 308 & 10 & 0 & 8 & 1 & 1 \\
\hline Greece & 65 & 61 & 4 & 1 & 1 & 0 & 2 \\
\hline Hong Kong & 261 & 213 & 48 & 0 & 47 & 0 & 1 \\
\hline India & 159 & 117 & 42 & 40 & 1 & 1 & 0 \\
\hline Ireland & 35 & 28 & 7 & 0 & 3 & 3 & 1 \\
\hline Israel & 25 & 19 & 6 & 1 & 0 & 3 & 2 \\
\hline Italy & 157 & 145 & 12 & 2 & 7 & 2 & 1 \\
\hline Japan & 2,173 & 2,081 & 92 & 1 & 87 & 3 & 1 \\
\hline Korea & 124 & 112 & 12 & 8 & 0 & 2 & 2 \\
\hline Malaysia & 244 & 233 & 11 & 11 & 0 & 0 & 0 \\
\hline Mexico & 71 & 41 & 30 & 3 & 15 & 2 & 10 \\
\hline Netherlands & 122 & 107 & 15 & 0 & 5 & 6 & 4 \\
\hline New Zealand & 36 & 36 & 0 & 0 & 0 & 0 & 0 \\
\hline Norway & 75 & 72 & 3 & 0 & 3 & 0 & 0 \\
\hline Pakistan & 20 & 18 & 2 & 1 & 1 & 0 & 0 \\
\hline Philippines & 65 & 59 & 6 & 2 & 3 & 1 & 0 \\
\hline Portugal & 34 & 29 & 5 & 2 & 1 & 0 & 2 \\
\hline Singapore & 130 & 121 & 9 & 0 & 9 & 0 & 0 \\
\hline South Africa & 113 & 95 & 18 & 0 & 13 & 5 & 0 \\
\hline Spain & 109 & 103 & 6 & 1 & 3 & 0 & 2 \\
\hline Sweden & 104 & 95 & 9 & 1 & 6 & 2 & 0 \\
\hline Switzerland & 141 & 137 & 4 & 0 & 4 & 0 & 0 \\
\hline Taiwan & 165 & 143 & 22 & 20 & 0 & 1 & 1 \\
\hline Thailand & 110 & 100 & 10 & 1 & 9 & 0 & 0 \\
\hline Turkey & 25 & 20 & 5 & 4 & 1 & 0 & 0 \\
\hline UK & 776 & 720 & 56 & 2 & 23 & 25 & 6 \\
\hline Total & 6,654 & 6,121 & 533 & 111 & 289 & 74 & 59 \\
\hline
\end{tabular}

Table 2. Descriptive Statistics

\begin{tabular}{|lrcrrlrrrr|}
\hline Variable & Mean & Std. Dev. & Min & Max & Variable & Mean & Std. Dev. & Min & Max \\
\hline CL & 0.08 & 0.27 & 0.00 & 1.00 & G_Law & 0.45 & 0.50 & 0.00 & 1.00 \\
EX_CL & 0.02 & 0.15 & 0.00 & 1.00 & S_Law & 0.05 & 0.22 & 0.00 & 1.00 \\
Reconcile & 0.23 & 0.16 & 0.00 & 1.00 & EmergM & 0.20 & 0.40 & 0.00 & 1.00 \\
Disclosure & 0.36 & 0.12 & 0.06 & 0.84 & Liquidity & 0.73 & 0.71 & 0.11 & 4.62 \\
CIFAR & 73.13 & 7.13 & 56.00 & 85.00 & LogGNP & 6.77 & 1.49 & 4.09 & 8.48 \\
Anti_D & 3.57 & 1.23 & 0.00 & 5.00 & Size & 5.89 & 0.68 & 5.00 & 8.92 \\
Jud_E & 9.00 & 1.64 & 3.25 & 10.00 & Growth & 8.56 & 51.57 & -100.00 & 1146.49 \\
E_Law & 0.32 & 0.47 & 0.00 & 1.00 & Leverage & 76.89 & 278.40 & -2834.68 & 5227.73 \\
F_Law & 0.18 & 0.39 & 0.00 & 1.00 & ROA & 4.14 & 8.71 & -69.45 & 116.00 \\
\hline
\end{tabular}

$C L=1$ if a firm is a cross-listed firm, and 0 otherwise; $E X_{-} C L=1$ if the firm is an exchange-listed firm, and 0 otherwise; Reconcile=sum of noncompliant items divided by 13 accounting method choices, representing a firm's reconciliation costs; Disclosure $=$ sum of non-disclosed items divided by 31 accounting method choices, representing a firm's disclosure costs; CIFER=a country-level disclosure index which rates companies' annual reports for their inclusion or exclusion of 85 items; InvestProtec=shareholders protection in the home country. Three measures are used: country legal origin, anti-director rights, and judicial efficiency (LLSV 1998); E_Law=1 if the firm is from an English common law system country, and 0 otherwise; $F_{-} L a w=1$ if the firm is from a French code law system country, and 0 otherwise; G_Law=1 if the firm is from a German code law system country, and 0 otherwise; $S_{-} L a w=1$ if the firm is from a Scandinavian code law system country, and 0 otherwise; Anti_D=index that aggregates six different shareholder right, ranging from 1 to 6 (highest); Jud_E=index of efficiency and integrity of legal environment, ranging from 1 to 10 (highest); $\operatorname{Emerg} M=1$ if the International Finance Corporation classifies a firm's home market as emerging, and 0 otherwise; Liquidity=the dollar value of shares traded divided by the average market capitalization in 1997(IFC Emerging Markets 
Factbook 1998); $\log G N P=\log$ of GNP (1997) in billions of U.S. dollars in the country; Size=log of total assets in millions of dollars as of 1999; Growth=net sales growth as of 1999 (in percentage); Leverage=long-term debt divided by common equity as of 1999 (in percentage); ROA=net income divided by total assets as of 1999 (in percentage); Industry=industry membership, 1-digit SIC code.

Table 3. Comparison between Cross-listed and Non Cross-listed Firms

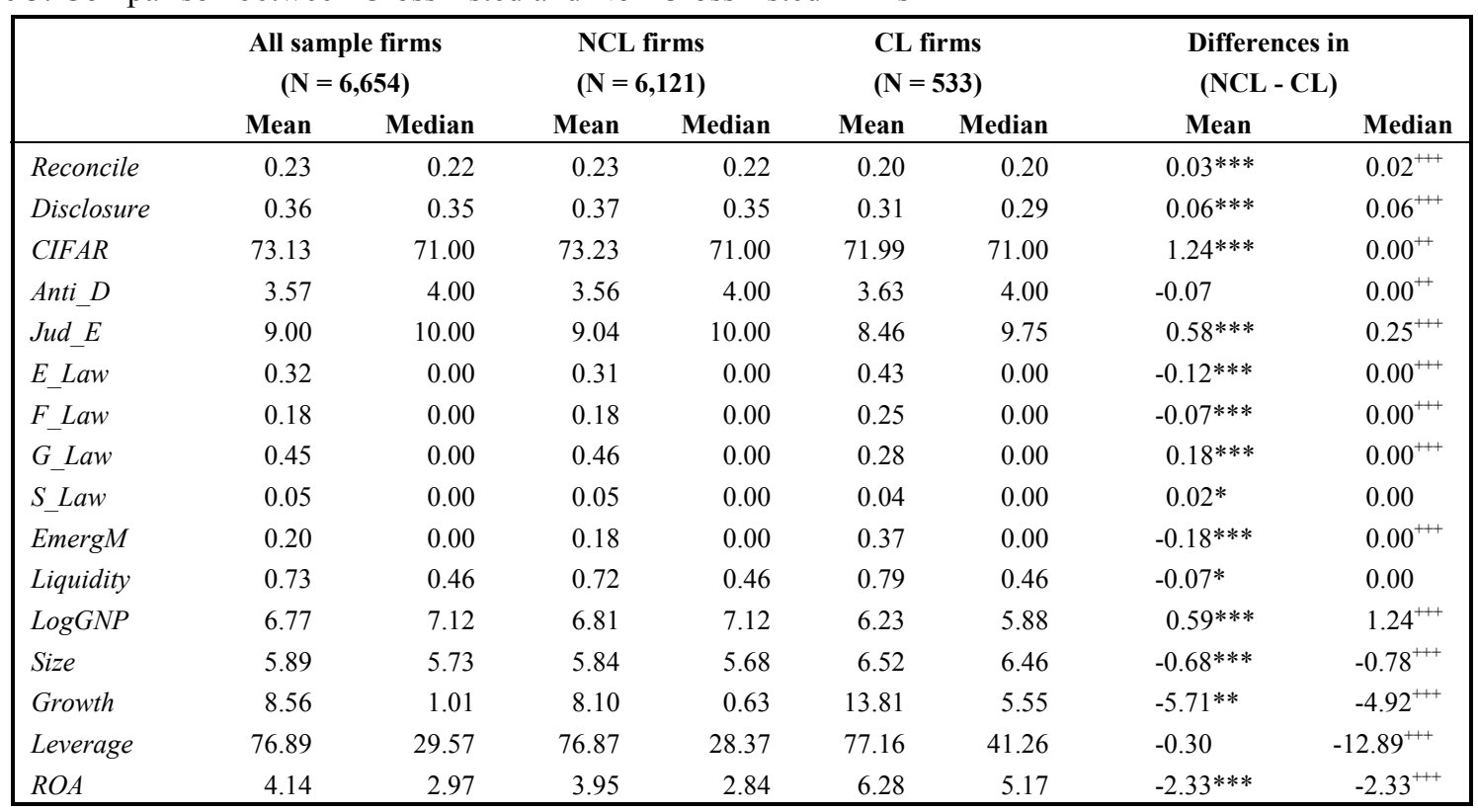

Tests for differences in means are based on paired t-tests. Tests for differences in medians are based on Wilcoxon rank-sum tests.

$* * *, * *, \quad$ The difference in means is significant at the $0.01,0.05$, and 0.1 level, respectively (two-tailed).

,,++++++ The difference in medians is significant at the $0.01,0.05$, and 0.1 level, respectively (two-tailed).

Table 4. Comparison between Exchange-listed and Non Exchange-listed Firms

\begin{tabular}{|c|c|c|c|c|c|c|c|c|}
\hline & \multicolumn{2}{|c|}{$\begin{array}{l}\text { All CL firms } \\
(\mathbf{N}=\mathbf{5 3 3})\end{array}$} & \multicolumn{2}{|c|}{$\begin{array}{l}\text { NEXL firms } \\
(\mathrm{N}=\mathbf{4 0 0 )}\end{array}$} & \multicolumn{2}{|c|}{$\begin{array}{c}\text { EXL firms } \\
(N=133)\end{array}$} & \multicolumn{2}{|c|}{$\begin{array}{l}\text { Differences in } \\
\text { (NEXL - EXL) }\end{array}$} \\
\hline & Mean & Median & Mean & Median & Mean & Median & Mean & Median \\
\hline Reconcile & 0.20 & 0.20 & 0.21 & 0.20 & 0.19 & 0.20 & 0.02 & 0.00 \\
\hline Disclosure & 0.31 & 0.29 & 0.32 & 0.32 & 0.28 & 0.29 & $0.04 * * *$ & $0.03^{+++}$ \\
\hline CIFAR & 71.99 & 71.00 & 70.92 & 71.00 & 75.23 & 78.00 & $-4.31 * * *$ & $-7.00^{+++}$ \\
\hline Anti_D & 3.63 & 4.00 & 3.68 & 4.00 & 3.49 & 4.00 & 0.19 & 0.00 \\
\hline$J u d_{-} E$ & 8.46 & 9.75 & 8.53 & 10.00 & 8.28 & 8.75 & 0.25 & 1.25 \\
\hline E_Law & 0.43 & 0.00 & 0.44 & 0.00 & 0.41 & 0.00 & 0.03 & 0.00 \\
\hline F_Law & 0.25 & 0.00 & 0.18 & 0.00 & 0.46 & 0.00 & $-0.28 * * *$ & $0.00^{+++}$ \\
\hline G_Law & 0.28 & 0.00 & 0.34 & 0.00 & 0.09 & 0.00 & $0.25 * * *$ & $0.00^{+++}$ \\
\hline S_Law & 0.04 & 0.00 & 0.04 & 0.00 & 0.05 & 0.00 & -0.01 & 0.00 \\
\hline EmergM & 0.37 & 0.00 & 0.36 & 0.00 & 0.38 & 0.00 & -0.02 & 0.00 \\
\hline Liquidity & 0.79 & 0.46 & 0.85 & 0.46 & 0.63 & 0.46 & $0.22 * * *$ & $0.00^{+++}$ \\
\hline $\log G N P$ & 6.23 & 5.88 & 6.28 & 5.88 & 6.06 & 6.00 & $0.22 *$ & -0.12 \\
\hline Size & 6.52 & 6.46 & 6.41 & 6.37 & 6.83 & 6.83 & $-0.42 * * *$ & $-0.46^{+++}$ \\
\hline Growth & 13.81 & 5.55 & 13.60 & 3.90 & 14.47 & 9.55 & -0.87 & $-5.65^{+++}$ \\
\hline Leverage & 77.16 & 41.26 & 78.13 & 38.68 & 74.25 & 45.04 & 3.88 & -6.36 \\
\hline$R O A$ & 6.28 & 5.17 & 5.78 & 4.62 & 7.78 & 7.19 & $-2.00 * *$ & $-2.58^{+++}$ \\
\hline
\end{tabular}

Tests for differences in means are based on paired t-tests. Tests for differences in medians are based on Wilcoxon rank-sum tests.

$* * *, * * \quad$ The difference in means is significant at the $0.01,0.05$, and 0.1 level, respectively (two-tailed).

,,++++++ The difference in medians is significant at the $0.01,0.05$, and 0.1 level, respectively (two-tailed). 
Table 5. Logit Regression of Cross-Listing

\begin{tabular}{|c|c|c|c|c|c|c|c|c|c|}
\hline & \multicolumn{3}{|c|}{ Model 1} & \multicolumn{3}{|c|}{ Model 2} & \multicolumn{3}{|c|}{ Model 3} \\
\hline & Coefficient & p-value & $\mathrm{dy} / \mathrm{dx}$ & Coefficient & p-value & $\mathrm{dy} / \mathrm{dx}$ & Coefficient & p-value & $d y / d x$ \\
\hline Intercept & $5.081 * * *$ & 0.000 & & $-4.491 * * *$ & 0.000 & & $-8.276 * * *$ & 0.000 & \\
\hline Reconcile & $-1.314 * * *$ & 0.000 & -0.075 & $-0.639 *$ & 0.104 & -0.025 & $-0.686^{*}$ & 0.081 & -0.024 \\
\hline Disclosure & $-5.131 * * *$ & 0.000 & -0.294 & $-4.866 * * *$ & 0.000 & -0.192 & $-1.239 * *$ & 0.039 & -0.043 \\
\hline CIFAR & $-0.075^{* * *}$ & 0.000 & -0.004 & $-0.066 * * *$ & 0.000 & -0.003 & $-0.055^{* * *}$ & 0.000 & -0.002 \\
\hline Anti_D & $0.150 * * *$ & 0.003 & 0.009 & $0.218^{* * *}$ & 0.000 & 0.009 & $0.238 * * *$ & 0.000 & 0.008 \\
\hline$F_{-}$Law & $-0.341 * *$ & 0.027 & -0.018 & $-0.465 * *$ & 0.011 & -0.016 & $-0.526 * * *$ & 0.004 & -0.016 \\
\hline G_Law & $-1.407 * * *$ & 0.000 & -0.080 & $-1.350 * * *$ & 0.000 & -0.053 & $-1.157 * * *$ & 0.000 & -0.040 \\
\hline S_Law & $-0.578 * *$ & 0.023 & -0.027 & -0.318 & 0.243 & -0.011 & $-0.451^{*}$ & 0.103 & -0.013 \\
\hline EmergM & & & & $0.804 * * *$ & 0.000 & 0.040 & $0.618 * * *$ & 0.000 & 0.026 \\
\hline Liquidity & & & & -0.009 & 0.904 & 0.000 & -0.042 & 0.564 & -0.001 \\
\hline $\log G N P$ & & & & -0.011 & 0.862 & 0.000 & $-0.178 * * *$ & 0.007 & -0.006 \\
\hline Size & & & & $1.351 * * *$ & 0.000 & 0.053 & $1.881 * * *$ & 0.000 & 0.066 \\
\hline Growth & & & & & & & 0.001 & 0.153 & 0.000 \\
\hline Leverage & & & & & & & $-0.001 * * *$ & 0.003 & -0.000 \\
\hline Industry & & & & & & & Included & & Included \\
\hline Pseudo $R^{2}$ & 0.083 & & & 0.206 & & & 0.236 & & \\
\hline Predicted & $C L=1)$ & & 0.061 & & & 0.041 & & & 0.036 \\
\hline
\end{tabular}

***, **, * indicate significance level, respectively, at 0.01, 005 and 0.1 level.

Table 6. Logit Regression of Exchange-Listing

\begin{tabular}{|c|c|c|c|c|c|c|c|c|c|}
\hline & \multicolumn{3}{|c|}{ Model 1} & \multicolumn{3}{|c|}{ Model 2} & \multicolumn{3}{|c|}{ Model 3} \\
\hline & Coefficient & p-value & dy/dx & Coefficient & p-value & $\mathrm{dy} / \mathrm{dx}$ & Coefficient & p-value & $\mathrm{dy} / \mathrm{dx}$ \\
\hline Intercept & $-6.935 * * *$ & 0.000 & & $-14.785^{* * *}$ & 0.000 & & $-17.897 * * *$ & 0.000 & \\
\hline Reconcile & -1.008 & 0.317 & -0.158 & -1.150 & 0.272 & -0.168 & -0.772 & 0.477 & -0.106 \\
\hline Disclosure & $-3.050 * * *$ & 0.007 & -0.478 & $-3.540 * * *$ & 0.005 & -0.518 & -1.754 & 0.265 & -0.240 \\
\hline CIFAR & $0.086^{* * *}$ & 0.000 & 0.013 & $0.099 * * *$ & 0.000 & 0.014 & $0.118 * * *$ & 0.000 & 0.016 \\
\hline Anti_D & 0.056 & 0.635 & 0.009 & 0.068 & 0.593 & 0.010 & 0.044 & 0.738 & 0.006 \\
\hline F_Law & $1.888^{* * *}$ & 0.000 & 0.368 & $1.692 * * *$ & 0.000 & 0.311 & $1.754 * * *$ & 0.000 & 0.309 \\
\hline G_Law & $-0.713^{*}$ & 0.100 & -0.101 & $-1.192 *$ & 0.053 & -0.148 & -0.970 & 0.129 & -0.115 \\
\hline S_Law & -0.167 & 0.768 & -0.025 & -0.076 & 0.898 & -0.011 & -0.144 & 0.816 & -0.019 \\
\hline EmergM & & & & $1.320 * * *$ & 0.000 & 0.216 & $1.268 * * *$ & 0.000 & 0.194 \\
\hline Liquidity & & & & 0.242 & 0.275 & 0.035 & 0.272 & 0.254 & 0.037 \\
\hline $\log G N P$ & & & & 0.118 & 0.421 & 0.017 & 0.017 & 0.916 & 0.002 \\
\hline Size & & & & $0.883^{* * *}$ & 0.000 & 0.129 & $1.203 * * *$ & 0.000 & 0.164 \\
\hline Growth & & & & & & & -0.001 & 0.710 & 0.000 \\
\hline Leverage & & & & & & & -0.000 & 0.766 & 0.000 \\
\hline Industry & & & & & & & Included & & Included \\
\hline Pseudo $\mathbf{R}^{2}$ & 0.177 & & & 0.239 & & & 0.284 & & \\
\hline Predicted $P$ & $\left.E X \_C L=1\right)$ & & 0.195 & & & 0.178 & & & 0.163 \\
\hline
\end{tabular}


Table 7. Comparison of Compliance Costs between Cross-listing Year and 3 Years Prior Cross-listing

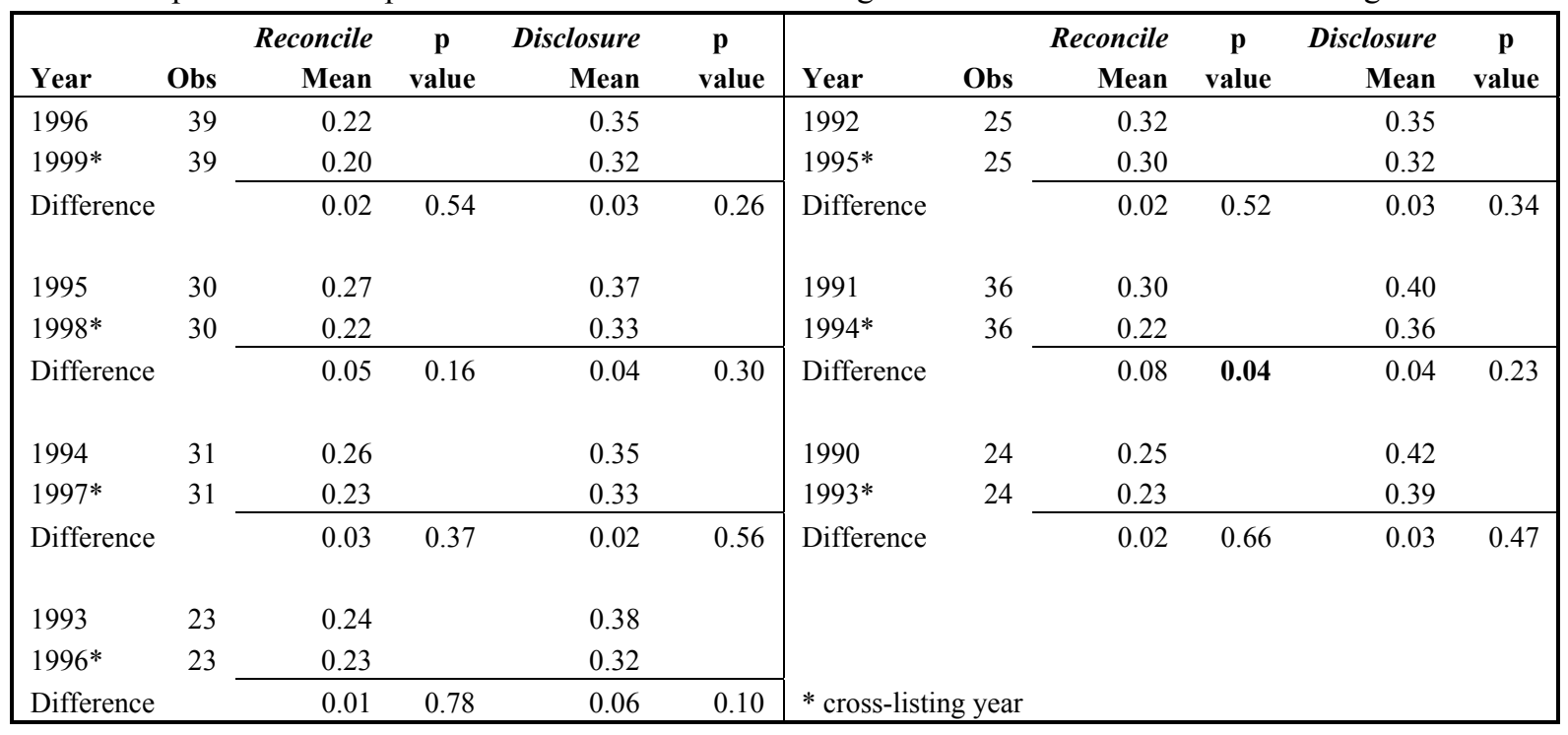

Table 8. Regressions with Country-Fixed Effect

\begin{tabular}{|lcc|}
\hline & H1 & H2 \\
\hline Intercept & $-12.568^{* * *}$ & $-6.133^{* * *}$ \\
Reconcile & $-1.582^{* * *}$ & 1.000 \\
Disclosure & $-2.102 * * *$ & $-4.506^{* *}$ \\
Size & $1.879^{* * *}$ & $1.255^{* * *}$ \\
Growth & 0.001 & -0.003 \\
Leverage & $-0.001^{* * *}$ & -0.000 \\
Industry & Included & Included \\
Country & Included & Included \\
& & \\
\hline & $\mathrm{N}=6,618$ & $\mathrm{~N}=471$ \\
Pseudo $\mathbf{R}^{\mathbf{2}}$ & $\mathbf{0 . 2 7 3}$ & $\mathbf{0 . 3 8 2}$ \\
\hline
\end{tabular}

$* * *, * *, *$ indicate significance level, respectively, at $0.01,005$ and 0.1 level.

Table 9. Regressions with Alternative Variable Definitions

\begin{tabular}{|lcc|}
\hline & H1 & H2 \\
\hline Intercept & $-6.860^{* * *}$ & $-16.307^{* * *}$ \\
L_Reconcile & $0.213^{*}$ & 0.061 \\
H_Reconcile & -0.020 & -0.506 \\
L_Disclosure & $0.709^{* * *}$ & 0.296 \\
H_Disclosure & $-0.570^{* * *}$ & -0.550 \\
CIFAR & $-0.064^{* * *}$ & $0.100^{* * *}$ \\
Anti_D & $0.214^{* * *}$ & 0.070 \\
F_Law & $-0.477^{* * *}$ & $1.753^{* * *}$ \\
G_Law & $-1.275^{* * *}$ & $-1.139^{*}$ \\
S_Law & -0.244 & -0.005 \\
EmergM & $0.806^{* * *}$ & $1.301^{* * *}$ \\
Liquidity & -0.009 & 0.272 \\
LogGNP & -0.024 & 0.120 \\
Size & $1.420^{* * *}$ & $0.909^{* * *}$ \\
Growth & 0.001 & -0.002 \\
Leverage & $-0.001^{* * *}$ & -0.000 \\
\hline & $\mathrm{N}=6654$ & $\mathrm{~N}=533$ \\
Pseudo $\mathbf{R}^{2}$ & $\mathbf{0 . 2 0 5}$ & $\mathbf{0 . 2 3 7}$ \\
\hline
\end{tabular}

***, **, * indicate significance level, respectively, at $0.01,005$ and 0.1 level. 


\section{Appendix A: Classification of Accounting Practices as Consistent or Inconsistent with US GAAP}

(Source: Bradshaw, Bushee and Miller 2004)

1. Accounting for goodwill

- Consistent: amortized; amortized and/or taken to reserves;

- Inconsistent: not amortized, expensed when incurred; written off at management discretion; taken to reserves

2. Accounting for other intangibles/deferred charges

- Consistent: amortized

- Inconsistent: capitalized, not amortized; expensed when incurred; capitalized, written off at management discretion; taken to reserves

3. Accounting for long term financial leases

- Consistent: capitalized and amortized

- Inconsistent: expenses; some capitalized and some expensed

4. Accounting method for long-term investments less than $20 \%$

- Consistent: cost; lower of cost and intrinsic value

- Inconsistent: equity; market value

5. Accounting method for long-term investments $21-50 \%$

- Consistent: equity; equity but consolidated where significant influence; equity and cost depending on significant influence

- Inconsistent: cost; cost but consolidated where significant influence; equity and proportional consolidation

6. Accounting method for long-term investments greater than $50 \%$

- Consistent: all subsidiaries are consolidated; consolidation for significant subsidiaries - others are on an equity or cost basis

- Inconsistent: domestic subsidiaries consolidated - others on a cost or equity basis; foreign subsidiaries consolidated - others on a cost or equity basis; no consolidation - cost or equity basis (parent company only)

7. Deferred taxes recorded

- Consistent: yes

- Inconsistent: no - taxes paid as incurred

8. Financial statements cost basis

- Consistent: historical cost entirely; historical cost with price-level adjustment on revaluation of specific accounts

- Inconsistent: historical cost with supplementary current cost financial information; current cost statements entirely; modified historical cost with supplemental current cost financial information; current cost with supplemental historical cost financial information

9. Funds definition on statements of changes in financial position

- Consistent: cash; modified cash; prior to 1989, other definitions acceptable under APB 19

- Inconsistent: working capital; modified working capital; unique definition; net borrowings; net liquid assets

10. Marketable securities valuation

- Consistent: lower of cost or market; historical cost; subsequent to 1993, current market value and cost with periodic valuation acceptable under SFAS115

- Inconsistent: current market value; moving average; weighted average; periodic average; cost with periodic revaluation

11. Research and development costs

- Consistent: expensed currently; for computer companies in SIC codes 5054, 7371, or 7372, capitalized and amortized later or some expensed some capitalized are considered consistent with US GAAP

- Inconsistent: capitalized and amortized later; expensed and capitalized later; some expensed, some capitalized

12. Starting line of statement of changes in financial position

- Consistent: net income, bottom line; prior to 1989, net income before minority interest, net income before extraordinary items, and other

- Inconsistent: net income before net allocations to reserves; net income before minority interest and taxes; unique; sales; sales plus other operating income; operating income; net income before interest; cash receipts; operating income before depreciation

13. Treasury stock location on balance sheet

- Consistent: deduction from shareholders' equity

- Inconsistent: long term investment; other assets; current assets

Appendix B: List of Disclosure Items

Accounting for foreign currency transaction gain/loss

Accounting for goodwill 
Accounting for long term financial leases

Accounting method for long term investment $<20 \%$

Accounting method for long term investment $>50 \%$
Accounting for other intangibles/deferred charges

Accounting method for long term investment 21-50\%

Accounting standards followed

Acquisition method

Contingent liabilities disclosed

Currency of financial report

Deferred taxes recorded

Depreciation method

Discretionary reserves

Earnings per share numerator used for computed ratio

Financial statements cost basis

Foreign currency translation method

Inventory costing method

Minority interest effect

Research \& development costs

Reason for changes in financial statement

Treasury stock gain/loss

Treasury stock location on balance sheet

Pension fund management

Funds definition on statement of changes in financial

$$
\text { position }
$$

Marketable securities classification

Pension fund contribution

Reason for extraordinary items

Starting line- changes in financial position

Auditor

Auditor's opinion 